\title{
Democracy, Information and Incentives
}

\author{
Jan-Erik Lane* \\ Prof emeritus at UNIGE, Geneva, Switzerland
}

*Corresponding Author: Jan-Erik Lane, Prof emeritus at UNIGE, Geneva, Switzerland

\begin{abstract}
What is true information in today's world? The hunt for information is on, not only in the private sector - market trends and enterprise data ' bur also on the public sector. Information is strongly linked with incentives: leak news and you have an extra rent. This paper tries to model the crucial role of information and it's incentives in government and it started in the public sector
\end{abstract}

Keywords: Opportunism, shirking, pretending, asymmetrical knowledge, Hobbes, Montesquieu

\section{INTRODUCTION}

Society consists of two parts, namely the public and the private sectors. The privet sector is made up of the myriad of individuals interacting whereas the public sector comprises two parts: public resource allocation and social security. While the understanding of the logic of contracting as well as the analysis of contract law has for long been essential to private sector theory and the market - size is set by law (Schmidtchen) only recently has there been forthcoming a framework for the analysis of the public sector as basically contracting. Sociologist J. S. Coleman called this modelling principal agent in his 1990 book.

Let us apply it onto the democratic regime where the principal is the demos facing three different types of agents: executive, legislative and judicial agents. These agents, of course, possess generally speaking an information advantage that they will to play with in interactions with each other and with the demos, not abstaining from opportunism with guile - incentives.

At the end of the Second World War, a few major books appeared debating the consequences of the defeat of right wing authoritarianism, one may mention books such as books by Danish Alf Ross, Swedish Herbert Tingsten as well as Italiano Giovanni Sartori and Dutch Arene Lijphart, They all focused om the value og democracy as a method for collective decision-making, i.e. for a nation or country, They approached democracy as a political regime, baser upon the consent og a majority of voters. And they saw a necessary condition for democratic stability in the endorsement of democratic election outcomes by a substantial part of the electorate,

The first scholar to look at the democratic regime economically was Anthony's Economic Theory of Democracy from 1957 models two party competition as a market game over vest winning position in space of voters attitudes, the median voter theorem of location. However, there is nothing here about the gains from democracy.

Why set up parties in the first place?

\section{THE NeEDS OF PEOPLE}

A democratic regime would find its rationale ultimately with the people of the country.

Their needs of government would be decisive for the means and ends of the state. But in political philosophy after WW2, we find theorized other ultimate objectives. If the state is the political organisation of the country all kinds of goals may be mentioned:

National power or aggrandisement, economic development, equality, rule of law, dictatorship of the proletariat or of the superior race, etc. Here I focus upon the demos as the principal, and the needs of government with the population. 
Who is the people? A democratic vision of the state presumes a potive attitude to single individuals and his or her capacity to instruct a set of agents in the branches of government. Democracy may not be ideal, but a platonic view is not recommendable. Neither Plato' philosophers nor Nietzsche ' Zoroaster would provide the demos with task of giving instructions to government and hold these agents responsible.

The demos is the electorate, as it provides instructions to government agents along various channels. If you distrust the people to give instructions for policy making, you can deny their knowledge competence like Plato or dispose their trivial needs and projects like Nietzsche, you will not support the idea of democratic process. One cannot help wondering why such a sick man like Nietzsche in Engadin admired so intensifying the "great men" like Caesar and Napoleon. They were in reality his opposite and he ridiculously declares himself the greatest of philosophers in his autobiography.

Democracy is government of the people, the electorate instructing political agents about the policies they want to be implemented. What, then, would be the best policies for the people? Many have thought about the real needs of the demos, but I will favour peace and lack of starvation as well as a safe environment. Let me discuss two other theories:

1) Primary goods: Rawls came up with this concept in order to identify what must be rendered to people in a well-ordered society: Basic mental and bodily abilities, liberty and opportunity, income and wealth, and basic self-respect, because they are desirable for every human being, and useful. When these needs of ordinary man and women are met, justice deliberations may begin.

This amounts to a too abstract approach to the question of what a well-ordered society is

Rights require an independent judiciary that exists in a minority of countries. What is more "primary" for people is survival, i.e. to live in peace and be able to feed oneself and breed in safety in the environment.

A majority of the population of the world does not posses several of these Rawlsian primary goods. Are they really their primary or most important objectives?

2) Capability: Sen has launched a different approach underlining each individual 's need for wellbeing: "Poverty is not just a lack of money; it is not having the capability to realize one's full potential as a human being", each person's capability that is. Capacity to what? A bad or evil person has also capabilities to well-being, right?

I believe Thomas Hobbes was on the correct line of thought when focusing on civil war: "Whatsoever therefore is consequent to a time of war, where every man is enemy to every man, the same consequent to the time wherein men live without other security than what their own strength and their own invention shall furnish them withal. In such condition there is no place for industry... no knowledge of the face of the earth; no account of time; no arts; no letters; no society; and which is worst of all, continual fear, and danger of violent death; and the life of man, solitary, poor, nasty, brutish, and short."

A country or society in a Hobbesian predicament is hardly worth living in. But it occurs from time to time. Periods of internal warfare or external aggression, famines or ecological disasters result IN enormous suffering for citizens. Lack of violence, access to food and safe shelter are the key "primary goods".

Hobbes saw a great authority as the mechanism to stop or prevent the "omnium bellum contract omnes" - monarchy. Hobbes suggested that a monarch would be more trustworthy in keeping peace, law and order than Parliament. Strange! Sed quid custody ipso custos? Hobbes argued simplistically that it is more likely that a group of people start quarreling and fighting between each other than a single individual would do that, so he outlined an authoritarian regime as the best. Hobbes failed to anticipate the principal-agent nature of political authority.

Spinoza did not. His Political Treatise was written a couple of years after Leviathan (1651) and offered a deep analysis of which regime would be the best given the egoism and aggressive behaviour of ordinary people? Although left unfinished, spinoza seems to have preferred democracy before monarchy and oligarchy on the basis of his assumption of selfishness of people: If each and every one puts his/her interests first, then the of the people would carry less risks than monarchy or oligarchy! 
What happens when the "people " is divided and cannot speak with one voice - Rousseau' ideal of a unanimous "people" with one Volkgeist? Rousseau refused to accept the practical necessity of representation, allowing only administrators to implement the will of the people.

In this romantic talk of "volunte generale" as well as the so called enemies of the people we have a principal-agent model that restrains the political agents as much as possible.

\subsection{Democracy without Agents: Transaction Costs}

Swiss economists often claim that their country has a superb constitutional set of arrangement, viz direct democracy at all levels of government in a genuine federation. The argument is linked nor to Rousseau and his General Will but to Swedish world-renowned Wicksell.

Wicksell searched for Pareto effective allocation of local public goods thar benefitted each and every one. Since the good is lumpy individual charges will not work. Somehow there must be an aggregation of the individual willingness to pay such that the entire cost of the public good is covered. Since the "people" may be divided in two groups - one very eager minority and a lukewarm majority the collective should reflect this fact, which is what unanimity does, forcing a common negotiated outcome.

However, Wicksell' theory falters on two grounds:

A) 0pportunism, the group of people less willing to pay can hold out forcing the other stakeholder to pay much more, which could result in endless negotiations;

B) It violates the rule of equality between YES and NO, favouring the status quo. What is unanimity concretely - cf the General Will?

Democratic decision-making is simple majority, with equal chance for YES or NO. However, Wicksell clearly foresaw that more costly decisions

Could require qualified majority. This amounts to an insight into the economic search of inertia rules in constitution.

The logic of Swiss democracy is not Wicksellian. It follows more political opportunity where small group use VOĹKSINITIATIV to overturn a law of Parliament as fewer than half of the electorate participates.

\subsection{Democracy and Party; Agency Costs}

Principal-agent modeling of political parties could adduce numerous attempts to capture a political "rent". The information asymmetrical advantages are all on the side of the party. We have in the large literature the following:

- Promise without intension to deliver

- False accusations or explanations of policy

- Denials of failure

- Use of public purse to pay for parties

- internal operation secrecy

- external animosity towards other parties and at times internal quarreling.

Yet, despite these misgivings political parties are dominant players in many countries be they wellordered or not. PARTITOCRAZIA may tempered by direct democracy - with few or many referenda. The evaluation of parties varies from one extreme - rip off agency - to another - cost effective transmission of signals from electorate to Parliament. Parties exist over the whole world, openly or clandestinely.

The logic is economies of collaboration: only highly charismatic politicians can handle all costs and burdens of an election. Ordinary politicians organise to share these efforts and divide the spoils afterwards. The party is keen about its reputation for honesty, cohesion and closeness to voters, fearing deviant behaviour of party members as much as voter volatile downside. 
The legislature and the population at large engage in principal-agent gaming continuously under each election period of 4 or 5 years. Legislative agents play with asymmetrical knowledge advantages saying that:

- policy errors are abundant or just exaggerated

- rules have been broken or they are denied

- ' the economy goes well or faces imminent disaster

- the environmental is threatened or just a little damaged

- new legislation is urgently needed but we are looking into the matter

- too many foreigners arrive and yet we need more labour.

The legislature organises itself into political parties who confront each other with ideology, blame game and opportunistic behaviour with guile. Coalitions are created ad hoc in order to meet the 51 per cent requirement.

\subsection{Democracy as Sovereignty of Parliament}

The principal-agent interactions inherent in the regime of a Parliament suzerain is shaped by the parties to a large extent. It so to speak unfetters the partitocrazia. This is British constitutional legacy from Cromwell, to be found in a few countries with historic ties to England.

Tactics as well as strategy on a Parliament suzerain fulfils all the implications of the theory of asymmetrical information in the relationship between principal and agents. Politics änd policymaking is in effect delegated to Parliament alone to be dominated by the Premier with no countervailing powers except a coming new election.

Minister Caesarism is an extreme principal-agent model mitigated only by Common Law and a few other legal documents. This is British constitutional practice, never codified. It plays out differently in Westminster and Singapore, being merely contingency political theory, only theorised by Bagshot stressing its Hobbesian tendencies when compared with the US constitutional outcome 1860 to 1865.

The "living" British Constitutional framework includes no legal review: How could Parliament be wrong? It could never enact rules that constrain its power tomorrow. This is the outcome of the oftenpresent feudal struggle, which in very few countries ended in Parliament victory over the King.

British constitutionalism is changing though, with devolution, human rights, Law Lords, referendum, et.c. Drawing upon recent events around so-called Brexit, one can say that the British people or electorate would benefit from judicial codification, as present confusion about minister Caesarism would subside.

When Parliament is incapable of designing a majority Premier, then the so-called Committee Parliamentary Government or simply an intermediary solution with caretaker, which neither promotes the principal's interests generally.

\subsection{Democracy as Checks and Balance}

Information about politically relevant events and circumstances is much sought after. The mass media turns it out all day long. Political agents strive to be the first to know but also the population often follows the stream of research on a daily basis. Montesquieu's separation of powers entails stating that there are three kinds of expertise - executive, legislative and judicial - and they are to be separated on the personal level.

Access to information as well as control of information is central in day-to-day political competition. New information alters the behaviour in principal-agent interactions. The dynamics of politics and policy are to a large degree influenced or even shaped by the flow of new information. The arrival of new domestic or international news may have profound impact on the principal and the political agents: government and its bureaucracy, legislative and the judiciary. In the search for correct information the principal may draw upon the separation of powers to reduce the asymmetric information advantage of agents, for instance by one agent engaging in oversight of another agent.

Modern constitutional democracy comes in two ideal-types: American presidentialism and constitutional monarchy or weak presidentialism. Both follow Montesquieu's separation of powers 
stating that the principal would be best off when government is divided onto three branches. In reality there are some institutional variations of the framing of these key powers. What benefits the principal here or the population/electorate? Let me point out:

\subsubsection{Judicial Autonomy}

In general, the principal wo welcome judicial integrity and the option to test public decision-making before the judiciary. More contested is the structure of legal review. Is it at all necessary for democratic decision-making?

\subsubsection{Judicial Oversight}

Enquiries into policy implementation by national government bureaux, agencies, boards or regional and local authorities are essential for reducing the information advantage of politicians and political parties. These enquiries may be recurring or special ones. The structure of judicial overview varies much from ordinary courts to special tribunals. Some countries have administrative courta as well as the Ombudsman -the Swedish, Danish or Swiss type.

\subsubsection{Complaint and Redress}

The position of the single individual is much buttressedoes when the practice of public administration can be challenged in some court somehow. The possibility of appeal has enormous impact, especially on anticipations or expectations on the of bureaucracy. The Scandinavian contribution to constitutionalism - OMBUDSMAN - is important for ordinary citizens.

Judicial enquiries can be done in several forms where for instance judges collaborate with legislators or experts from public administration.

\subsubsection{Legislation}

Politicians in the legislature ' or groups of them like parties - have a strong wish to get re-elected for various reasons like position, income, prestige or good work. At elections one expects that falsity occurs as lying or exaggerations could pay off.

Peltzman models the strategy of rational politicians to present a policy mix maximizing the probability of electoral victory.

In order to reduce their information gap in relation to the executive and public administration the legislature engages in oversight of public programs and the use of public money. A variety of oversight committees and boards are available for legislatures to make enquiries into program performance, both legality and efficiency. Not only the US and other presidentialisms have procedures for disclosure of executive malpractice, but also parliamentary regimes - large institutional variation.

To be a legislator earns you prestige and, in several countries, good money, as in the EU Parliament. The American system with PACS (political action committees) leads to huge budgets for legislators seeking election or re-election. However, legislative oversight is hampered by the influence of organized interests, lobbying both policymaking and policy implementation - the capture theory.

\section{Premier, President And Public Administration}

The executive has a range of agencies at its command. Can they be trusted? As responsible for the performance in almost all public programs the executive depends upon the flow of information. How can the executive control for asymmetrical information - the basic incentives problematic in public administration?

The amount of resources controlled by the executive as well as the bureaucracy and public enterprise sector under its wings is normally overwhelming. The public sector comprises public resource allocation and transfer payment, making up between 20-55 per cent of GDP, depending on the political-economy regime of the country. How are these resources to ne used, ideally as well as employed reality?

\subsection{Classic Public Finance Models}

A penetrative attempt to derive a rational and just public sector for an advanced economy was made in the so-called public finance approach. The lessons of this exercise were also relevant for Third World 
countries. Using criteria on rationality in resource allocation as well as some criterion on justice in social security the public sector would remove market failures of various kinds.

The successful public finance models were to be found in the analysis of efficiency, micro or macro. But the concept of income and wealth redistribution towards more of social justice proved very contested among social scientists and economists as well as philosophers. How much and in what forms?

Consider, please, the difference between ultra liberal Nozick - no redistribution - and socialist Barry equalise until impartiality. In any case the book by the Musgraves from 1980 is still instructive Public Finance in Theory and Practice.

\subsection{Politics and Administration}

In most European countries there is somehow a separation between the recruitment of public employees on the hand and politicians on the other hand. Thus, when there is a change of government in the. UK, France and Germany the bureaucracy remains the same. This pattern may also be found in regional and local governments. The argument is that the bureaucracy is merely a machine to be employed by the master or politicians in power. The higher echelons are neutral and may serve any political party ruling. Matters are different in the USA.

In American public administration the distinction between politics and administration is accepted in neither theory nor practice. In practice the so-called spoils system applies, the incoming president may recruit a large number of public officials rewarding his/her team in the election Theoretically, Appelby rejected any separation in Policy and Administration from 1949 - policymaking is always political just as well as judicial review.

Weber believed that policy and implementation had two distinct components: ends and means. To deliberate upon and decide about goals and their priority is the key task of politicians whereas the considerations of the efficacy of the means or tools of policy belong to the experts in the bureaucracy. By offering bureaucrats and professionals a secure position in the bureau, the political elite would guarantee access to expertise knowledge.

If means-end relationships are crucial in policy and implementation, then the choice between alternative means is value ingrained. Some countries have put in politically recruited personal at the apex of hierarchy of each bureaucracy but not on the scale of what is Washington practice. In policy implementation public employees are generally seen as under obligation to implemented objectives ends and means - even though they would wish to engage in resistance to change. Should there be much resistance to change by old and large bureaucracy, the government as principal may decide to cut it up into smaller bureaux - agencification or even a sharper reply with outsourcing.

\subsection{Asymmetrical Information}

Recognising the information advantage of the -executive and her/his agents forces one to acknowledge the role of opportunism with guile in political affairs. Enter things into the public sector like:

- insincere voting

- vote trading or cycling

- embezzlement

- bribery

- kickback

- conflict of interest

- mishandling of emails

- unlawful threat

- favouritism or patronage

- tribalism

- ineffiency

- deliberate misinformation 
- dishonesty

- negligence or intended lack of competence

- misuse of competence, power and office

- prebendalization,

- $\quad$ vote fraud.

The difference between constitutional democracy and other regimes is merely the comprehensive occurrence of these selfish tactics as well as the systematic absence of corrections and disclosure. The people as the ultimate principal of the polity can only be vigilant as electorate as well as instruct legislative and judicial agents to check and balance the executive and public administration. At the end of the line the firing option must be employed.

The quality of the public sector can only be protected by countervailing powers. Countries that are illfated drown in government mismanagement. A country where an elite rule unhindered allows the capture of a huge rent for politicians.

\section{CONCLUSION}

The postmodern society is information writ large: quantity, speedy access, control, etc. When a person is more informed, he or she sees the opportunities that come with it and tries to capitalise upon it. In public sector information asymmetry is a most important source of power and perhaps rent.

In the history of political thought, we encounter two philosophers who are especially relaxant for the principal-agent framework, viz Hobbes and Montesquieu. The first recognised the close link between anarchy and politics whereas the second understood the link between separation of powers and political order and freedom.

Is a new theory of politics possible on the basis of how information is handled tactically and strategically? What is now played out in Washington and Westminster suggest so. Politics focuses on how to tell false information from true as well as how to spread it. Democracy is the ideal-type regime for these games, as it pits the public at large against three different agents: executives, legislators and judges. Shirking and pretending will sooner or later be confronted with true information, which is why democracy is superior.

\section{REFERENCES}

[1] Appleby, P.: Politics and Administration. 1949, University of Alabama Press, Tuscaloosa, AL, United States.

[2] Arrow, K.: Social choice and Individual Values. 1951, John Wiley and Sons, Hoboken, NJ, United States.

[3] Barry, B.: Justice as Impartiality. 1995, Clarendon Press, Oxford, United Kingdom.

[4] Brams, S.J.: Game Theory and Politics. 1975, Free Press, New York, NY, United States.

[5] Campbell, D.E.: Incentives. Cambridge University Press, cambridge, United Kingdom.

[6] Coleman, J.S.: Foundations of Social Theory. 1990, Harvard University Press, Cambridge, MA, United States.

[7] Hobbes, T.: Leviathan. 1651, London, England.

[8] Laffont, J.J.: The Theory of Incentives: The Principal-Agent Model. 2002, Princeton University Press, Princeton, New Jersey, United States.

[9] Montesquieu: The Spirit of the Laws. 1748, Paris, France.

[10] Nozick, R.: Anarchy, State and Utopia. 1974, Basic Books, New York, NY, United States.

[11] Nurmi, H.: Comparing Voting Systems. 1987, D. Reidel, Dordrecht, Netherlands.

[12] Peltzman, S.: The Growth of Government. Journal of Law and Economics, vol. 23 (1980), p. 209.

[13] Rawls, J.: A Theory of Justice.1971, Harvard University Press, Cambridge, MA, United States.

[14] Ross, A.: Why Democracy? . 1952, Harvard University Press, Cambridge, MA, United States

[15] Rousseau, J.J.: The Social contract. 1762, Paris, France.

[16] Sen, A.: Commodities and capabilities. 1985, Oxford University Press, Oxford, United Kingdom.

[17] Sen, A.: Development as Freedom. 1999, Albert A. Knopf, New York, NY, United States. 
[18] Spinoza, B.: Political Treatise. 2000, Hackett Publishing Co., Cambridge, MA, United States.

[19] Tingsten, H.: The Problem of Democracy. 1965, Bedminster Press.

[20] Wicksell, K.: A New Principle of Just Taxation. Classics in the Theory of Public Finance, pp. 72-118. 1967, Macmillan, London, United Kingdom Spinoza, B.: Political Treaties.

[21] Williamson, O.: Markets and Hierarchies: Some Elementary Considerations. 1973, American Economic Review, vol. 63, pp. 316-325.

Citation: Jan-Erik Lane. "Democracy, Information and Incentives" International Journal of Political Science (IJPS), vol 5, no.4, 2019, pp. 27-34. doi: http://dx.doi.org/10.20431/2454-9452.0504005.

Copyright: (C) 2019 Authors. This is an open-access article distributed under the terms of the Creative Commons Attribution License, which permits unrestricted use, distribution, and reproduction in any medium, provided the original author and source are credited. 